\title{
Ducky Mouse Phenotype of Epilepsy and Ataxia Is Associated with Mutations in the Cacna2d2 Gene and Decreased Calcium Channel Current in Cerebellar Purkinje Cells
}

\author{
Jane Barclay, ${ }^{1}$ Nuria Balaguero, ${ }^{2}$ Marina Mione, ${ }^{3}$ Susan L. Ackerman, ${ }^{4}$ Verity A. Letts, ${ }^{4}$ Jens Brodbeck, ${ }^{2}$ \\ Carles Canti, ${ }^{2}$ Alon Meir, ${ }^{2}$ Karen M. Page, ${ }^{2}$ Kenro Kusumi, ${ }^{5}$ Edward Perez-Reyes, ${ }^{6}$ Eric S. Lander, ${ }^{5}$ \\ Wayne N. Frankel, ${ }^{4}$ R. Mark Gardiner, ${ }^{1}$ Annette C. Dolphin, ${ }^{2}$ and Michele Rees ${ }^{1}$ \\ ${ }^{1}$ Department of Paediatrics and Child Health, Royal Free and University College Medical School, The Rayne Institute, \\ London, WC1E 6JJ, United Kingdom, Departments of 2 Pharmacology and ${ }^{3}$ Anatomy and Developmental Biology, \\ University College London, London, WC1E 6BT, United Kingdom, ${ }^{4}$ The Jackson Laboratory, Bar Harbor, Maine 04609, \\ ${ }^{5}$ Whitehead Institute for Biomedical Research, Cambridge, Massachusetts 02142, and ${ }^{6}$ Department of Pharmacology, \\ University of Virginia Health System, Charlottesville, Virginia 22908-0735
}

The mouse mutant ducky, a model for absence epilepsy, is characterized by spike-wave seizures and ataxia. The ducky gene was mapped previously to distal mouse chromosome 9. High-resolution genetic and physical mapping has resulted in the identification of the Cacna2d2 gene encoding the $\alpha 2 \delta 2$ voltage-dependent calcium channel subunit. Mutations in Cacna2d2 were found to underlie the ducky phenotype in the original ducky $(d u)$ strain and in a newly identified strain $\left(d u^{2 J}\right)$. Both mutations are predicted to result in loss of the full-length $\alpha 2 \delta 2$ protein. Functional analysis shows that the $\alpha 2 \delta 2$ subunit increases the maximum conductance of the $\alpha 1 \mathrm{~A} / \beta 4$ channel combination when coexpressed in vitro in Xenopus oocytes.
The $\mathrm{Ca}^{2+}$ channel current in acutely dissociated $d u / d u$ cerebellar Purkinje cells was reduced, with no change in singlechannel conductance. In contrast, no effect on $\mathrm{Ca}^{2+}$ channel current was seen in cerebellar granule cells, results consistent with the high level of expression of the Cacna2d2 gene in Purkinje, but not granule, neurons. Our observations document the first mammalian $\alpha 2 \delta$ mutation and complete the association of each of the major classes of voltage-dependent $\mathrm{Ca}^{2+}$ channel subunits with a phenotype of ataxia and epilepsy in the mouse.

Key words: epilepsy; ataxia; calcium channel; subunit; Purkinje cell; cerebellum; mouse mutant
Five spontaneous autosomal recessive mouse mutations impart a phenotype that includes epileptic seizures with features similar to those occurring in human idiopathic generalized epilepsy (IGE) (Puranam and McNamara, 1999). Tottering (Cacna1a ${ }^{\text {tg }}$, Cacna1a $\left.{ }^{\text {tg-la }}\right)$, slow-wave epilepsy (Slc9a1 $\left.{ }^{\text {swe }}\right)$, lethargic $\left(\right.$ Cacnb $\left.4^{\text {lh }}\right)$, stargazer (Cacng2 $2^{\text {stg }}$, Cacng2 $\left.2^{\text {stg-wag }}\right)$, and ducky $(d u)$ exhibit bilaterally synchronous spike-wave discharges (SWDs) on cortical electroencephalogram (EEG) recordings. These are accompanied by behavioral arrest and respond to the human anti-absence drug ethosuximide (Noebels et al., 1997). The electrophysiological hallmark of human absence epilepsy is $3 \mathrm{~Hz}$ SWDs. In mice, the frequency is usually $5-7 \mathrm{~Hz}$ (Noebels, 1991), except for those in Slc9a1 ${ }^{\text {swe }}(1-3 \mathrm{~Hz})$ (Cox et al., 1997). Mutations in genes encoding voltage-dependent calcium channel (VDCC) subunits underlie three of these pheno-

Received March 2, 2001; revised May 10, 2001; accepted June 1, 2001.

This work was supported by the Medical Research Council (UK), The Wellcome Trust, the Epilepsy Research Foundation, and National Institutes of Health Grants NS32801 (to V.A.L.) and NS31348 (to W.N.F.). We thank Dr. David Hosford and Randy Byers for generously sharing their expertise; Mick Keegan, Chantal Longo, Jo-Maree Courtney, and Eileen Sun for excellent technical assistance; the Human Genome Mapping Project Resource Centre for access to resources; and Hannah Mitchison and Anna-Elina Lehesjoki for useful comments.

N.B. and M.M. contributed equally to this work.

Correspondence should be addressed to Michele Rees, Department of Paediatrics and Child Health, Royal Free and University College Medical School, The Rayne Institute, 5 University Street, London, WC1E 6JJ, UK. E-mail: m.rees@ucl.ac.uk.

J. Barclay's present address: Novartis Institute for Medical Sciences, 5 Gower Place, London WC1E 6BS, UK.

Copyright (C) 2001 Society for Neuroscience $0270-6474 / 01 / 216095-10 \$ 15.00 / 0$ types: the genes encoding the $\alpha 1 \mathrm{~A}$ (Cacnala), $\beta 4$ (Cacnb4), and $\gamma 2$ (Cacng2) subunits are mutated in tottering (Fletcher et al., 1996), lethargic (Burgess et al., 1997), and stargazer (Letts et al., 1998) mice, respectively.

Voltage-dependent $\mathrm{Ca}^{2+}$ currents have been measured in all excitable cells and are implicated in many cellular processes (Berridge et al., 1998). They have been divided on the basis of kinetics and pharmacology into L-, N-, P/Q-, R-, and T-types (Catterall, 1998). Each VDCC is composed of a pore-forming $\alpha 1$ subunit that may be associated with an intracellular $\beta$, a membrane-spanning $\gamma$, and a membrane-anchored, but predominantly extracellular, $\alpha 2 \delta$ subunit. The $\alpha 1$ subunit determines the main biophysical properties of the channel and is modulated by the other subunits (Walker and De Waard, 1998). Mammalian genes encoding $10 \alpha 1$, four $\beta$, eight $\gamma$, and three $\alpha 2 \delta$ subunits have been identified (for a comprehensive list, see Ertel et al., 2000; Burgess et al. 2001).

Homozygotes for the ducky $(d u)$ allele are characterized by an ataxic, wide-based gait and paroxysmal dyskinesia (Snell, 1955). They display reduced size and a failure to breed or survive beyond $35 \mathrm{~d}$. Neuropathological studies revealed dysgenesis of selective regions of the CNS, including the cerebellum, medulla, and spinal cord (Meier, 1968). Axonal dystrophy and demyelination were also reported. Heterozygotes show no obvious phenotype. The $d u$ locus was localized to mouse chromosome 9 by linkage to the phenotypic markers dilute and short ear (Snell, 1955).

To identify and characterize the $d u$ locus, a positional cloning strategy was adopted. High-resolution genetic mapping identified 
the gene encoding the VDCC $\alpha 2 \delta 2$ subunit as a positional and functional candidate. Mutations in this gene were identified in the original $d u$ strain and in a new allele, $d u^{2 J}$. This paper presents evidence that the gene underlying the ducky phenotype encodes the $\alpha 2 \delta 2$ subunit and explores the effect of a mutation on $\mathrm{Ca}^{2+}$ channel function in $d u / d u$ brain.

\section{MATERIALS AND METHODS}

\section{Genetic and physical mapping}

Mice were obtained from The Jackson Laboratory (Bar Harbor, ME). DNA was prepared from tail biopsies or liver samples by standard methods. Microsatellite markers were amplified as described previously (Dietrich et al., 1996). Recombinants were identified by agarose gel electrophoresis or PAGE or single-strand conformation polymorphism (MDB1432) analysis. Yeast artificial chromosome (YAC) clones were identified by PCR-based library screens (Haldi et al., 1996) or from a web-based database of clones (Nusbaum et al., 1999). Genomic clones were obtained from the Human Genome Mapping Project Resource Centre (Cambridge, UK).

\section{Candidate gene analysis}

Total RNA was prepared from frozen tissue using RNAzol B (Biogenesis, Sandown, NH) and used to prepare mRNA or cDNA using mRNA purification or First Strand cDNA synthesis kits (Amersham Pharmacia Biotech, Little Chalfont, UK). Northern blot analysis of $10 \mu \mathrm{g}$ of cerebellar mRNA using Duralon UV nylon membrane and full-length Cacna $2 d 2$ or human $\beta$ actin as probes (Stratagene, La Jolla, CA) was performed using the suggested conditions of the manufacturer to optimize the identification of the wild-type $5.5 \mathrm{~kb}$ Cacna $2 \mathrm{~d} 2$ transcript. This may have resulted in underestimation of the quantity of smaller transcripts $(<2 \mathrm{~kb})$. The full-length Cacna2d 2 cDNA was assembled using degenerate primers, reverse transcription (RT)-PCR, rapid amplification of cDNA ends (RACE), and sequencing. All primer sequences are available on request. RACE was performed using the $5^{\prime} / 3^{\prime}$ RACE kit (Roche Diagnostics, Hertfordshire, UK). Sequencing was performed on an ABI 373XL sequencer using TaqFS chemistry (PE Applied Biosystems, Foster City, CA). Genomic DNA was embedded in agarose and subjected to pulsed field gel electrophoresis (PFGE) on a Bio-Rad (Hercules, CA) clamped homogeneous electrical field electrophoresis system.

\section{Electrode implantation and EEG measurements}

Homozygous $d u^{2 J}$ and control unaffected mice (8-12 weeks of age) were tested for spontaneous seizure activity. Mice were anesthetized with tribromoethanol $(400 \mathrm{mg} / \mathrm{kg}$, i.p. $)$ and placed in a stereotaxic holder fitted with a mouse incisor bar. Burr holes were drilled $(1 \mathrm{~mm}$ posterior to bregma, $1 \mathrm{~mm}$ lateral to midline) on both sides of the skull. Two Teflon-coated bipolar electrodes were implanted at $0.4-0.8 \mathrm{~mm}$ below the dura. Three screws were placed at the periphery of the skull to anchor the dental cap. Mice were allowed to recover for $2 \mathrm{~d}$ before EEG recordings were measured. The parameters for determining spike-wave discharges were described previously (Hosford et al., 1995).

\section{In situ hybridization and immunohistochemical analyses}

Mice [aged postnatal day 21 (P21) to P24] were terminally anesthetized by $\mathrm{CO}_{2}$ inhalation and perfused with $4 \%$ paraformaldehyde. The brain was dissected into cold paraformaldehyde and then transferred through a sucrose gradient before embedding in OCT (Agar) and sectioning. Alternatively, the brain was removed without fixing and frozen in liquid nitrogen. Cryostat sections $(10-15 \mu \mathrm{m})$ were cut and air dried onto positively charged slides (BDH Laboratory Supplies, Poole, UK).

cDNA fragments corresponding to $\alpha 2 \delta 2$ [nucleotide (nt) 3705-4909], $\alpha 2 \delta 1$ (nt 3521-3895), and $\alpha 2 \delta 3$ (nt 2581-3602) were subcloned into pBluescript SK+. Sense and antisense RNA probes were prepared using $\mathrm{T} 3$ or T7 polymerase and digoxigenin (DIG) RNA labeling mix and purified using Quick spin columns (Roche Diagnostics). In situ hybridization was performed as described previously (Eisenstat et al., 1999).

Immunohistochemistry was performed on perfused tissue and isolated cells with a polyclonal calbindin D28K antibody (Chemicon, Harrow, UK) and on perfused tissue alone with a polyclonal calretinin antibody (Chemicon).

\section{Heterologous expression of cDNAs}

cDNAs encoding rabbit $\alpha 1 \mathrm{~A}$ (X57689), rat $\beta 4$ (LO2315), and mouse $\alpha 2 \delta 2$ (predominant brain splice variant that lacks exon 23 and 6 bp of exon 38, as described by Barclay and Rees, 2000) cDNAs, cloned into the pMT2 vector, were injected intranuclearly into Xenopus oocytes as described previously (Canti et al., 1999), except that $4 \mathrm{nl}$ of cDNA mixture was injected at $1 \mu \mathrm{g} / \mu \mathrm{l}$. Recordings were made using two-electrode voltage clamp as described previously (Canti et al., 1999).

\section{Purkinje cell and granule cell preparation and $I_{B a}$ measurement}

Purkinje neurons. Cells were dissociated from P4-P8 mice (Mintz et al., 1992) and plated onto concanavalin-A $(2 \mu \mathrm{g} / \mathrm{ml})$-coated coverslips. Whole-cell $I_{\mathrm{Ba}}$ was recorded $1-4 \mathrm{hr}$ later with $5 \mathrm{mM} \mathrm{Ba}^{2+}$ as described previously (Mintz et al., 1992). Purkinje cell (PC) identity was confirmed by positive calbindin immunostaining $(n>70)$.

Cerebellar granule cells. Granule cells (GCs) were isolated and cultured from $\mathrm{P} 6-\mathrm{P} 8$ mice, and whole-cell $I_{\mathrm{Ba}}$ was recorded as described previously using $10 \mathrm{mM} \mathrm{Ba}^{2+}$ (Pearson et al., 1995), except that the internal pipette solution contained (in mM): 100 HEPES, 30 EGTA, $0.57 \mathrm{CaCl}_{2}$, 2.25 $\mathrm{MgCl}_{2}, 3.68 \mathrm{ATP}$, and 0.1 GTP (Tris salt), pH 7.2 (320 mOsm).

Cells were used for analysis when the holding current at the holding potential was $<20 \mathrm{pA}$ for GCs and $<50 \mathrm{pA}$ for PCs. The holding current did not differ between genotypes. Leak current was subtracted using P/8 protocol. Individual $I-V$ relationships were fitted with the modified Boltzmann equation $I=G_{\max } *\left(V-V_{\text {rev }}\right) /\left(1+\exp \left[-\left(V-V_{50}\right) / k\right]\right)$, where $G_{\max }$ is the maximum conductance, $V_{\text {rev }}$ is the reversal potential, $k$ is the slope factor, and $V_{50}$ is the voltage for $50 \%$ current activation.

\section{Single-channel recording}

All recordings were performed as described by Meir et al. (2000). Experiments were performed on cell-attached patches from PCs at room temperature $\left(20-22^{\circ} \mathrm{C}\right)$. Recording pipettes were pulled from borosilicate tubes (World Precision Instruments, Sarasota, FL), coated with Sylgard (Sylgard 184; Dow Corning, Wiesbaden, Germany), and fire polished to form high-resistance pipettes $\left(\sim 10 \mathrm{M} \Omega\right.$ with $\left.100 \mathrm{mM} \mathrm{BaCl}_{2}\right)$. The bath solution was composed of (in mM): $135 \mathrm{~K}$-aspartate, $1 \mathrm{MgCl}_{2}$, 5 EGTA, and 10 HEPES (titrated with $\mathrm{KOH}, \mathrm{pH} 7.3$ ). The patch pipettes were filled with a solution of the following composition (in $\mathrm{mM}$ ): $100 \mathrm{BaCl}_{2}, 10$ tetraethylammonium (TEA)-Cl, 10 HEPES, and $200 \mathrm{nM}$ $\mathrm{TTX}$, titrated with TEA-OH to $\mathrm{pH}$ 7.4. Both solutions were adjusted to an osmolarity of $320 \mathrm{mOsm}$ with sucrose. Data were sampled (Axopatch 200B and Digidata 1200 interface; Axon Instruments, Foster City, CA), at $5 \mathrm{kHz}$ and filtered on-line at $1 \mathrm{kHz}$. Voltages were not corrected for liquid junction potential (Neher, 1995) measured to be $-15 \mathrm{mV}$ in these solutions.

Leak subtraction was performed by averaging segments of traces with no activity from the same voltage protocol in the same experiment and subtracting this average from each episode using pClamp6 (Axon Instruments). Event detection was performed using the half-amplitude threshold method. Single-channel amplitude was determined by either a Gaussian fit to the binned amplitude distributions or the mean amplitude in two experiments at $+10 \mathrm{mV}$ when there was a small number of events.

All results are presented as mean \pm SEM, and statistical differences were determined by the Student's $t$ test.

\section{GenBank accession numbers}

DNA and protein sequences described here have been deposited in GenBank under the following accession numbers: wild-type Cacna2d2, AF247139; $d u$ mutant transcript 1, AF247140; $d u$ mutant transcript 2, AF247141; and $d u^{2 J}$ mutant transcript, AF247142.

\section{RESULTS}

\section{Genetic and physical mapping of the du locus}

Two genetic crosses were used to refine the location of $d u$ (Fig. 1a). Progeny representing 1460 meioses (564 backcross progeny and 448 intercross progeny) were typed with microsatellite markers 53.6-63.4 centimorgans (cM) from the centromere on mouse chromosome 9 (Dietrich et al., 1996). This region was assembled in overlapping yeast artificial chromosome (YAC) clones (Fig. 1b). Sequence tagged sites (STSs) to Dag1 and Lamb2 (Skynner 
$\boldsymbol{a}$

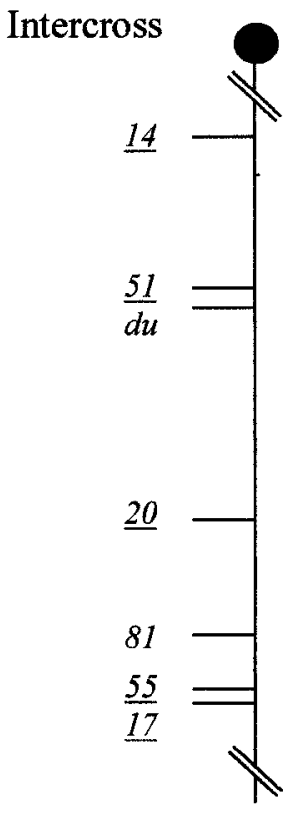

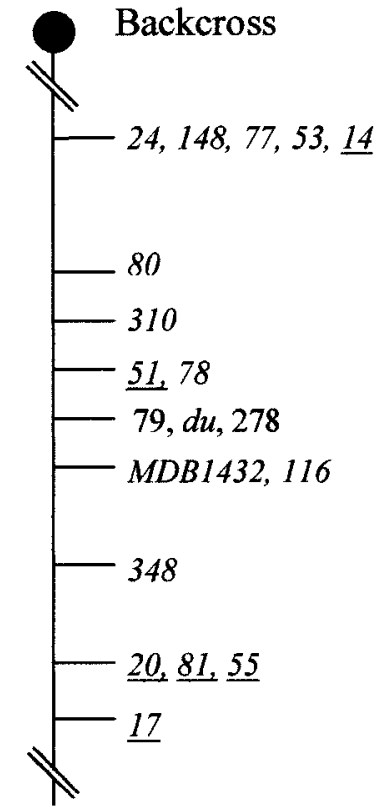

b

$310517879 \quad$ Cacna2d2 278

MDB1432 359116

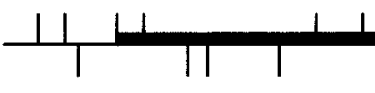
败

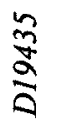

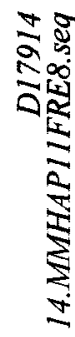

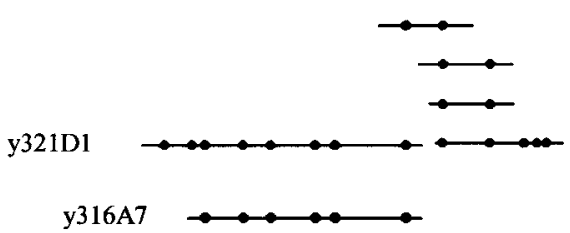

p428C5

p432G2

p52408

p524G24

y316A7

y203E7

y257D12
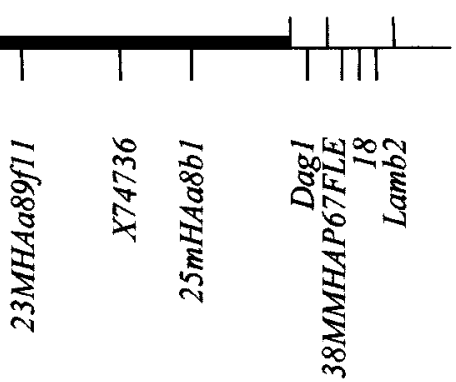

$\overline{100} \mathrm{~kb}$
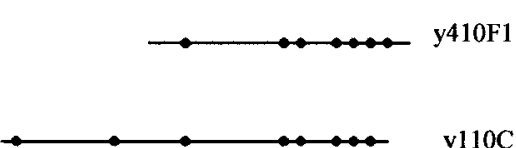

y110C11
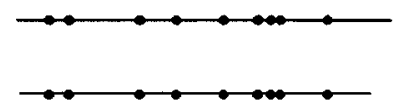

y465F 1
Figure 1. Genetic and physical maps define the $d u$ critical region. $a$, Genetic map around the $d u$ locus. The relation of the $d u$ gene to markers is shown to scale on partial chromosome linkage maps. Eight hundred ninety-six meioses of the (TKDU- $+/ d u \times$ STOCK $\left.D l l 3^{p u}+T y r^{c-c h} /+p T y r^{c-c h}\right) \mathrm{F} 1$ intercross place $d u$ between D9Mit51 and D9Mit20 (2.9 $\pm 0.1 \mathrm{cM})$. Five hundred sixty-four meioses from an intersubspecific backcross [(TKDU- $+/ d u \times$ CAST/ Ei) $\times$ TKDU- $+/ d u]$ show that $D 9 M i t 78$ and $M D B 1432$ flank $d u$, placing it in a $0.8 \pm 0.3 \mathrm{cM}$ interval. D9Mit prefixes have been removed from the markers for clarity. Underlined markers were typed in both crosses. $b$, Physical map of the $d u$ region. Markers ordered genetically are shown above the horizontal line, and those ordered on the physical map only are placed below. The region around $d u$ is indicated by a filled bar. A contig of YACs was assembled as illustrated. Library identification is prefixed with $y$. Four PAC clones are indicated and prefixed with $p$. Marker content in genomic clones is indicated by filled circles aligned with markers on the physical map. Gene symbols are as follows: Sema3B, semaphorin $3 B ; \quad$ Dag1, dystroglycan1; Lamb2, laminin $\beta 2$. et al., 1995) localized both genes distal to the $d u$ critical region (Fig. 1b). The human orthologs of these genes map to chromosome 3p21 (Skynner et al., 1995). The STS sequences D31943, M13963, and X85990 demonstrated significant similarities with CISH (Uchida et al., 1997), GNAT1 (Blatt et al., 1988), and SEMA3B (Sekido et al., 1996), respectively. These genes map to human $3 \mathrm{p} 21.3$, indicating that the $d u$ gene is in a region of conserved linkage with this region.

\section{Cacna2d2 is a candidate gene for the $d u$ locus}

Cacna $2 d 2$ was identified as a candidate gene for $d u$ as a direct result of the conservation of linkage of human chromosome
3 p21.3 with this region of mouse chromosome 9. Human chromosome 3 p21.3 is frequently deleted in small cell lung carcinoma and has been the target of positional cloning efforts. One transcript (human gene $C A C N A 2 D 2$; GenBank accession number AF042792) isolated from this region showed 55.6\% homology with the $\alpha 2 \delta 1$ VDCC subunit gene (Klugbauer et al., 1999; Gao et al., 2000). Two mouse expressed sequence tags (GenBank accession numbers AA000341 and AA008996) with 91 and 82\% nucleotide identity to $C A C N A 2 D 2$ were identified by Basic Local Alignment Search Tool analysis. This mouse sequence (gene Cacna2d2) was used to design a genomic PCR assay to test YACs 


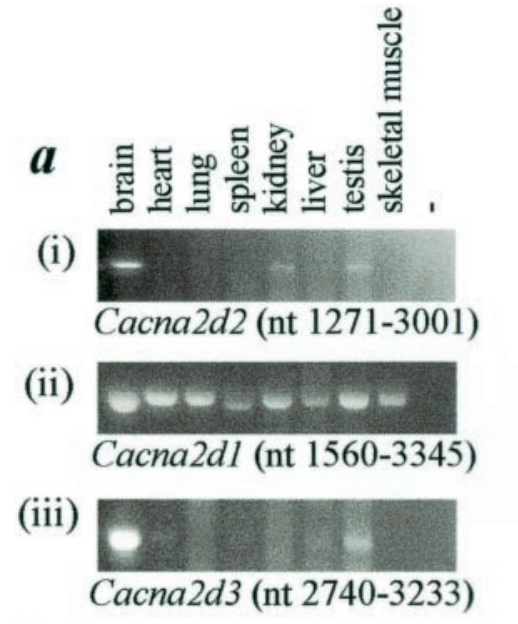

(iv)

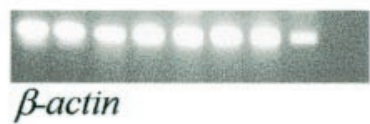

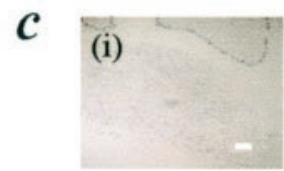

(iv) (ii)

(v)

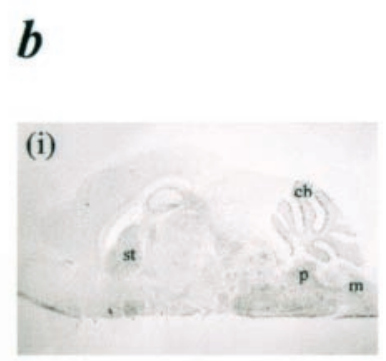

(ii)

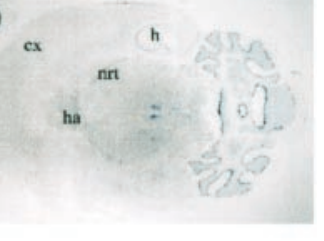

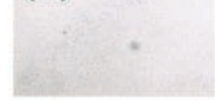

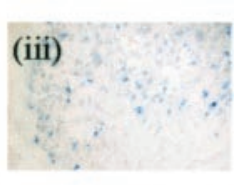

(vi)

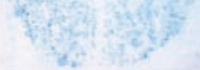

\section{Cacna2d2 is predominantly expressed in mouse brain in a restricted pattern}

The predominant Cacna2d2 transcript is in brain, with lower levels in kidney and testis (Fig. 2ai), a pattern distinct from Cacna2d1 (Fig. 2aii) but similar to Cacna2d3 (Fig. 2aiii). By RT-PCR, no Cacna $2 d 2$ expression was detected in lung at any age studied (1, 2, 6, and 20 months), a result confirmed using two additional sets of PCR primers (data not shown). Detailed Cacna $2 d 2$ brain expression was studied by in situ hybridization. A Cacna2d2 antisense RNA probe (exons 38-39) was hybridized to sections of P21 +/+ mouse brain. Analysis of whole-brain sagittal sections (Fig. 2bi) revealed the highest level of expression to be in the cerebellum, with moderate levels in medulla, pons, and striatum. Analysis of horizontal sections (Fig. 2bii) also shows expression in cortex, hippocampus, habenula, and nucleus reticularis thalami (nRT). Figure $2 c$ shows higher-resolution images of medulla $(i)$, striatum (ii), cerebral cortex (iii), nRT (iv), habenula $(v)$, and hippocampus (vi). No signal was detected with a control sense probe (data not shown). Cerebellar expression is investigated further in Figure 5, demonstrating that the gene is highly expressed in PCs with only very low levels in the granule cell layer (GCL) (see Fig. 5e).

\section{Cacna2d2 is mutated in $d u / d u$ mice}

No full-length Cacna2d2 transcript was detected by RT-PCR in $d u / d u$ mice. A failure of amplification between exon 1 and 4-39 implied disruption of the gene (Fig. 3ai, top and middle panels). Additional analysis identified two distinct mutant transcripts. 3' RACE of Cacna2d2 RNA in $d u / d u$ identified a chimeric transcript (mutant transcript 1) composed of exons 1, 2, and 3 spliced to a novel sequence (X). RT-PCR using primers for Cacna2d2 exon 1 and region $\mathrm{X}$ gave a $d u$-specific product (Fig. 3ai, bottom panel). Mutant transcript 1 encodes the first 414 nucleotides of Cacna2d2, followed by 24 novel nucleotides and a stop codon. Amplification between exons 1 and 3 (Fig. 3ai, top panel) reveals a low level of mutant transcript 1 in $d u / d u$ mice. A low level of mutant transcript 2 (exons 2-39) is also detected by RT-PCR in $d u / d u$ brain (Fig. 3aii). Wild-type Cacna2d2 (5.5 kb) and these mutant transcripts sized $\sim 1.5$ and $5 \mathrm{~kb}$ can be detected by Northern analysis of $+/+$ and $d u / d u$ cerebellar mRNA, respectively (Fig. 3b).

The presence by RT-PCR of the two mutant transcripts in $d u / d u$ mice suggested a duplication of exons 2 and 3, although additional bands were not detected by standard agarose gel electrophoresis and Southern blotting (data not shown). In contrast, PFGE and Southern blotting revealed a large genomic rearrangement (Fig. 3c). Exons 1 and 4-39 are present once per + and $d u$ chromosome. This is demonstrated by the presence of single 190 $\mathrm{kb}$ Not $\mathrm{I}$ hybridizing fragments with the probe corresponding to these exons (Fig. 3ci,ciii) in both genotypes. Exons 2-3 and region $\mathrm{X}$ are present once per + chromosome and twice per $d u$ chromosome, as indicated by the single (190 kb) and double (190 and $600 \mathrm{~kb}$ ) NotI fragments (Fig. 3cii), respectively. This supports a genomic duplication of exons $2-3$ and region $X$. The large size $(>150 \mathrm{~kb})$ of this duplication precludes its identification by conventional PCR and sequencing or Southern blotting because internal primer sites and restriction sites have been duplicated without disruption, preventing any distinction between original and duplicated exons. The wild-type position of region $\mathrm{X}$ as $3^{\prime}$ to the Cacna2d2 gene was confirmed by PCR amplification of the PAC clones (Fig. 1b). In genomic DNA, the copy of region $\mathrm{X}$ common to $+/+$ and $d u / d u$ contains two $\mathrm{B} 2$ repeat elements, and $\alpha 2 \delta 2$ shares $95 \%$ identity and $96.5 \%$ similarity with the human protein. from the $d u$ contig. Three positive clones (y203E7, y257D12, and y465F1) placed Cacna2d2 between D17914 and M13963, within overlapping Cacna2d2-positive P1-artificial chromosomes (PACs) orientated the gene as $5^{\prime}$ to $3^{\prime}$ in a proximal to distal direction (Fig. $1 b)$. An intragenic $(\mathrm{CA}) n$ repeat $(\alpha 2 \delta 2-43.21)$ was nonrecombinant with $d u$ in the backcross. Therefore, Cacna $2 d 2$ was a good positional and functional candidate for $d u$.

The $5.5 \mathrm{~kb}$ Cacna2d2 cDNA (GenBank accession number AF247139) shared 91\% nucleotide identity with CACNA2D2. The genomic structure of the Cacna $2 d 2$ gene has been determined (see Fig. 3d) (Barclay and Rees, 2000). Overall, mouse 

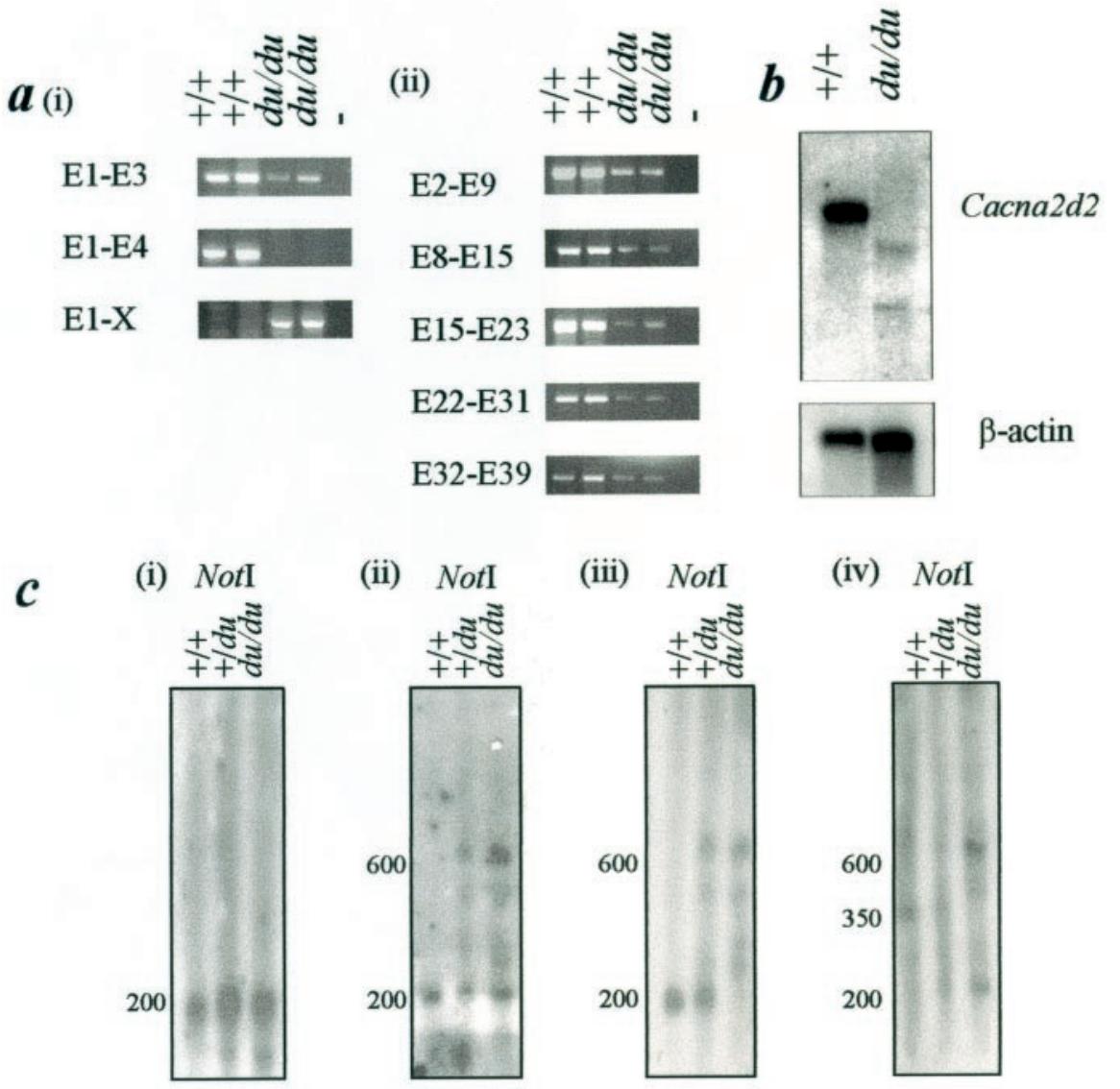

Probe: Exon 1

\begin{abstract}
Exons 4-39
\end{abstract}

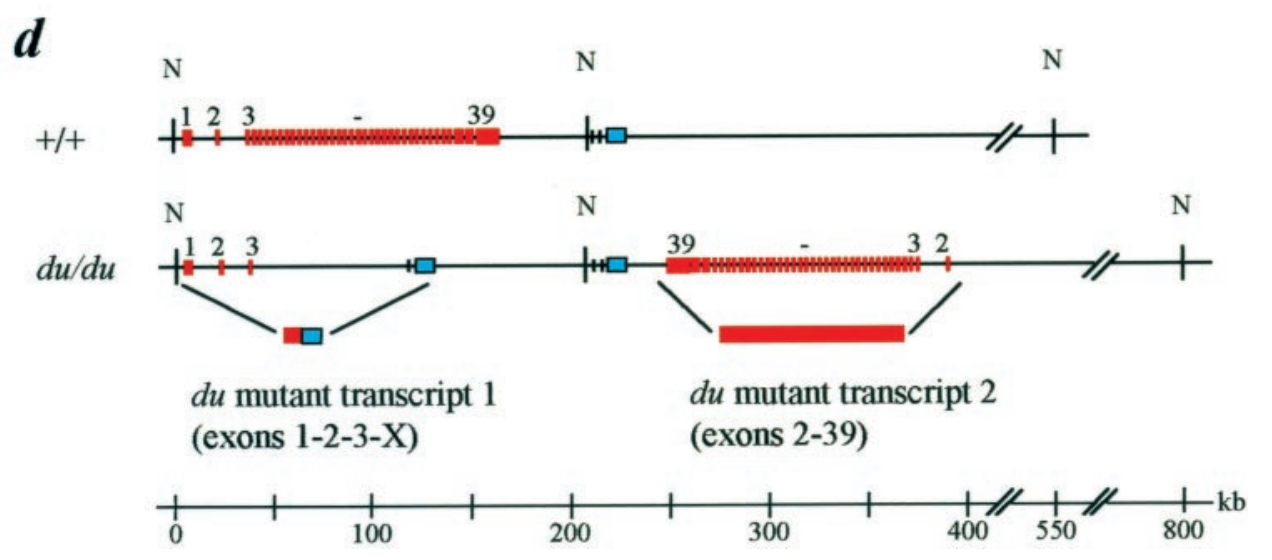

Figure 3. The $d u$ mutation is a genomic rearrangement involving the Cacna2d 2 gene. $a$, Two mutant transcripts can be identified by RT-PCR of total brain RNA from $d u / d u$ mice. Two $+/+$, two $d u / d u$ samples, and a negative control (no RNA) are shown per gel. $i$, Top, Normal size amplification product of exons 1-3 is shown in $+/+$ and $d u / d u$ RNA, with reduced levels in the latter. Middle, Amplification between exons 1 and 4 does not produce a product in $d u / d u$ RNA, suggesting disruption of the Cacna2d2 gene in this region. Bottom, Amplification of the $d u$-specific chimeric transcript of Cacna2d2 exons 1,2, and 3 and a novel sequence X. $i i$, Overlapping PCR fragments spanning exons 2-39 of Cacna2d 2 can be detected in $+/+$ and $d u / d u$ RNA, with lower levels observed in $d u / d u$ samples. $b$, Wild-type Cacna2d 2 transcript $(5.5 \mathrm{~kb})$ is absent from $d u / d u$ brain by Northern analysis using cerebellar mRNA and full-length Cacna2d 2 as a probe. Low levels of two $d u$-specific bands $(\sim 1.5$ and 5 $\mathrm{kb})$ are detected. The filter was rehybridized with $\beta$-actin as a control for RNA loading. $c$, PFGE shows duplication of Cacna2d2 exons 2 and 3 and region $\mathrm{X}$ in $d u / d u$ genomic DNA. Southern analysis of NotI-digested genomic DNA separated by PFGE from $+/+,+/ d u$, and $d u / d u$ mice is shown. Blots were hybridized with Cacna $2 d 2$ probes: $i$, exon 1 ; ii, exons $2-3$; iii, exons 4-39; $i v$, region X. Sizes are in kilobases. $d$, A scale representation of the genomic region containing Cacna2d2 (red) and region X (blue) in $+/+$ and $d u / d u$ mice. $N$, NotI sites. The presence of one or two $\mathrm{B} 2$ repeats $5^{\prime}$ to region $\mathrm{X}$ is marked by a vertical line. The mutant transcripts 1 and 2 produced from each region in $d u / d u$ are represented by colored boxes. The Cacna $2 d 2$ gene is arranged $5^{\prime}$ to $3^{\prime}$ in $+/+$. In $d u / d u$, exons encoding mutant transcript 1 are shown in a $5^{\prime}$ to $3^{\prime}$ direction, and those encoding mutant transcript 2 are inverted and shown $3^{\prime}$ to $5^{\prime}$. The distance between exon 3 and region $\mathrm{X}$ is unknown but is $>12 \mathrm{~kb}$. The scale bar is in kilobases. the $d u$-specific copy contains a single B2 repeat (Fig. 3d). A plausible mutation mechanism, possibly mediated by the $\mathrm{B} 2$ repeats, is a head to tail duplication of Cacna2d2 exons 2-39 and region $X$, followed by a deletion including exons 4-39 of the original Cacna2d2.

\section{A second, distinct mutation of Cacna2d2 in $d u^{2 J} / d u^{2 J}$ mice}

Recently, a spontaneous, autosomal recessive mouse mutant, with ataxia and paroxysmal dyskinesia, arose at The Jackson Laboratory. Breeding experiments established it as a novel ducky allele: $d u^{2 J}$. Cortical EEG recordings from $d u^{2 J} / d u^{2 J}$ revealed infrequent bilateral SWDs of high amplitude $(500 \mu \mathrm{V})$ and 5-7 Hz (Fig. 4a). These spontaneous discharges were accompanied by behavioral arrest. To determine whether these discharges were seizure related, an intraperitoneal injection of ethosuximide $(100 \mathrm{mg} / \mathrm{kg})$ was given, and the discharges were abolished.

Mutational analysis of Cacna2d2 in $d u^{2 J} / d u^{2 J}$ mice by RT-PCR and genomic sequencing revealed a 2 bp deletion (TG) within exon 9 (Fig. $4 b$ ) predicted to cause premature truncation of the protein (GenBank accession number AF247142). Sequence analysis of 45 subclones of the $d u^{2 J} / d u^{2 J} \mathrm{RT}$-PCR product failed to detect any wild-type transcript (data not shown). Northern analysis of mRNA from $d u^{2 J} / d u^{2 J}$ brain showed no difference in 
$\boldsymbol{a} \quad$ Left

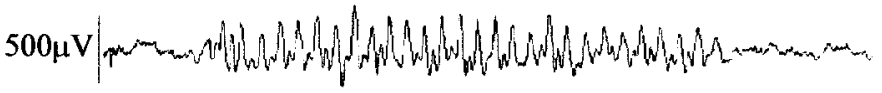

Right

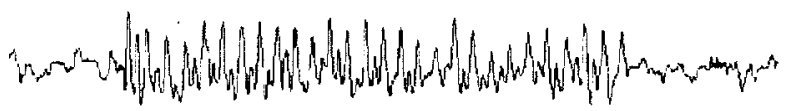

$1 \mathrm{sec}$

b
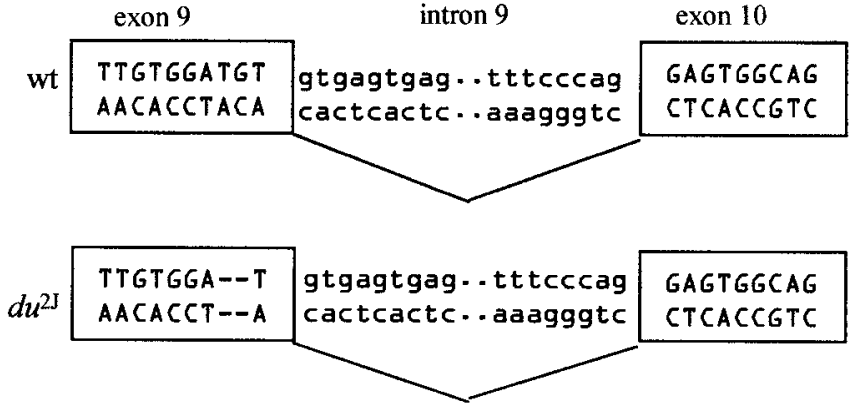

Figure 4. $d u^{2 J} / d u^{2 J}$ mice show 5-7 Hz SW D on cortical EEG and a 2 bp deletion in Cacna2d2. a, Representative EEG recordings of seizures from homozygous $d u^{2 J} / d u^{2 J}$ mice $(n=8)$. Low- and high-frequency filters were set at 0.3 and $35 \mathrm{~Hz}$, respectively. Traces from cortical bipolar electrodes implanted in the left and right hemispheres are illustrated. These spikewave discharges accompanied behavioral arrest. Control mice $(n=2)$ showed no abnormal activity (data not shown). $b$, Schematic representation of exons 9 and 10 and intron 9 of the Cacna2d2 gene in $+/+$ and $d u^{2 J} / d u^{2 J}$ genomic DNA.

Cacna2d2 transcription levels compared with wild type (data not shown), suggesting stability of the mutated transcript.

These observations suggest that Cacna2d2 mutations in $d u / d u$ and $d u^{2 J} / d u^{2 J}$ mice underlie the ducky phenotype of ataxia, SWDs, and paroxysmal dyskinesia.

\section{Immunohistochemistry of $d u / d u$ Purkinje and granule cells reveals no cell loss}

In view of the cerebellar pathology in $d u / d u$ mice, we wanted to identify whether there was any loss of PCs or GCs that might be responsible for this. However, immunohistochemical investigations using calbindin as a PC marker (Fig. $5 a, b$ ) and calretinin as a GC marker (Fig. $5 c, d$ ) did not identify loss of cell bodies in $d u / d u$ cerebella at P21 (Fig. 5b,d). Similar observations were made for $d u^{2 J} / d u^{2 J}$ (data not shown).

\section{Absence of full-length $\alpha \mathbf{2} \delta 2$ in $d u / d u$ cerebellar Purkinje cells}

In situ hybridization with a 3' Cacna2d2 anti-sense RNA probe (Fig. $5 e, f$ ) was used to demonstrate the presence of full-length Cacna2d2 message in $+/+$ PCs (Fig. $5 e$ ) and its absence in $d u / d u$ PCs (Fig. 5f).

The possibility of compensatory upregulation of Cacna2d1 (Fig. 5g,h) and Cacna2d3 (Fig. 5i,j) transcript levels in $d u / d u$ cerebella was investigated by in situ hybridization with antisense RNA probes. No major differences were observed in their distri-
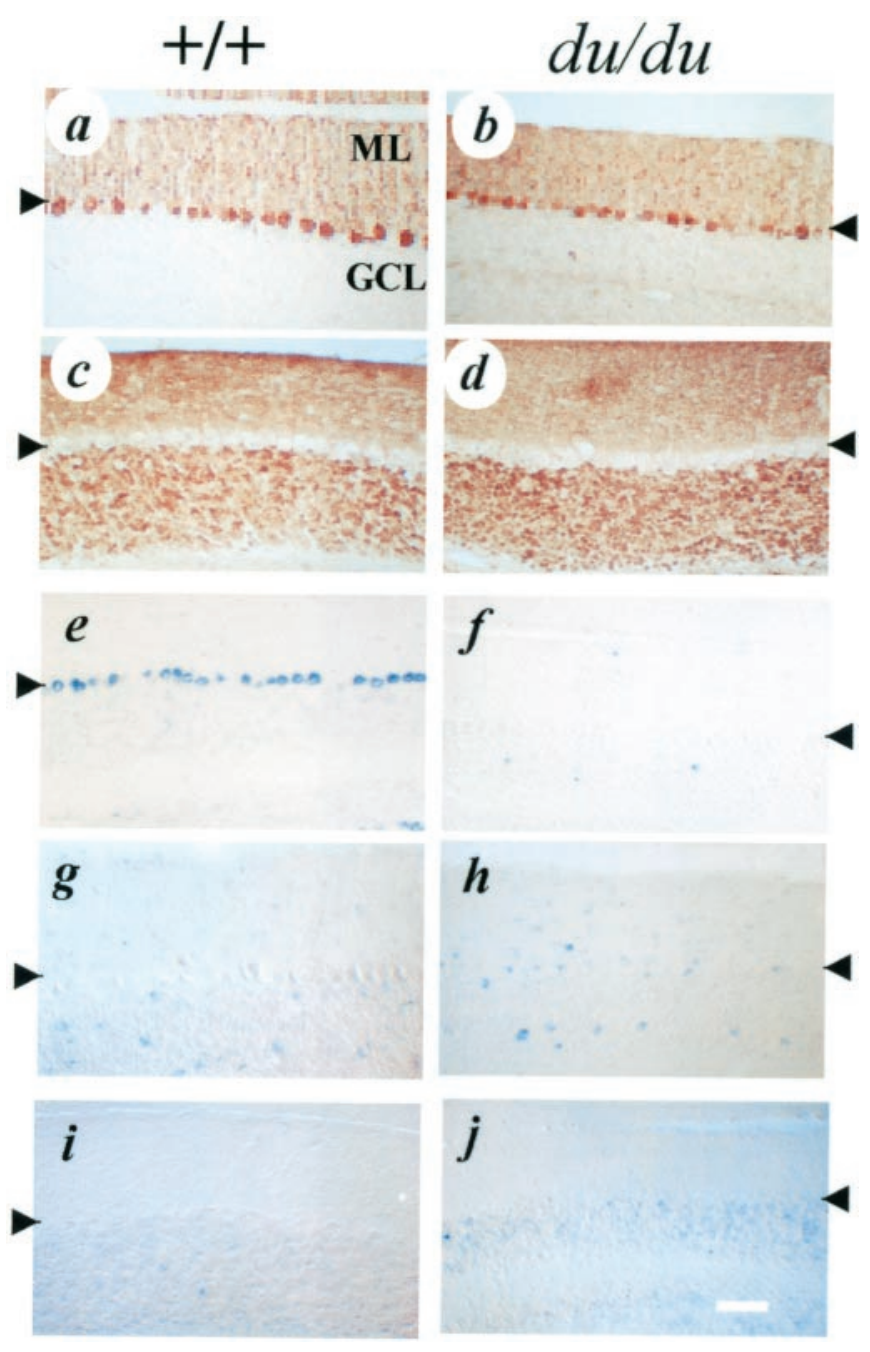

Figure 5. Analysis of Cacna2d2, Cacna2d1, and Cacna2d3 expression in cerebellum of $\mathrm{P} 21+/+$ and $d u / d u$ mice. $a, b$, Immunohistochemical detection of calbindin showing no obvious differences in PC number in $d u / d u(b)$ compared with $+/+(a)$ cerebellum. $c, d$, Calretinin immunostaining shows no difference in GC staining between $+/+(c)$ and $d u / d u$ $(d)$ cerebellum. In situ hybridization of $+/+$ and $d u / d u$ sections with a $3^{\prime}$ Cacna2d 2 antisense RNA probe. Analyses were performed on $+/+(e)$ and $d u / d u(f)$ sections. This probe does not detect any expression in the $d u / d u$ PCs $(f)$. In situ hybridization with Cacna2d1 $(g, h)$ and Cacna2d3 $(i, j)$ probes. (For $a-j, n=3$ for each genotype and experiment.) For all three riboprobes used, no signal was detected on hybridization of control sense RNA to $+/+$ sections (results not shown). Scale bar: $a-j, 100 \mu \mathrm{m}$. The PCL is indicated by an arrowhead, and the ML is uppermost in all sections. A small region of cerebellum is shown throughout for clarity.

bution in $d u / d u$ compared with $+/+$ cerebellum, and in particular there was no compensatory expression of $\alpha 2 \delta 1$ or $\alpha 2 \delta 3$ mRNA in $d u / d u$ PCs.

\section{Modulation of $\mathrm{Ca}^{2+}$ channel currents by $\alpha 2 \delta 2$}

The physiological function of the $\alpha 2 \delta 2$ subunit encoded by the Cacna2d2 gene was investigated using in vitro expression and electrophysiology. To mimic the composition of the predominant calcium channels in cerebellar Purkinje cells, we examined the effect of $\alpha 2 \delta 2$ when coexpressed with $\alpha 1 \mathrm{~A}$ and $\beta 4$ in Xenopus oocytes. Coexpression of $\alpha 2 \delta 2$ induced a large enhancement of $\alpha 1 \mathrm{~A}$ current amplitude (Fig. $6 a, b)$. For example, at $0 \mathrm{mV}$, the increase was from $-0.55 \pm 0.15(n=14)$ to $-1.8 \pm 0.27 \mu \mathrm{A}(n=$ $13)$, and there was a small hyperpolarization of current activation, 


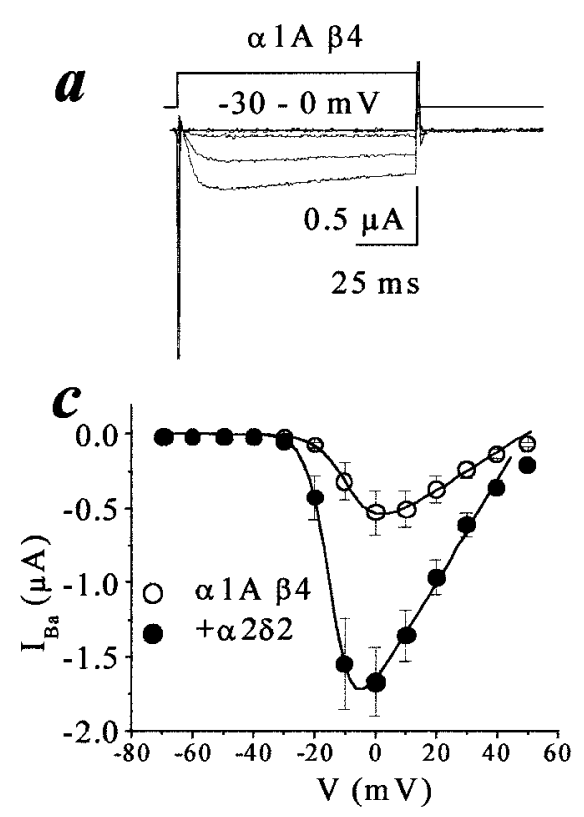

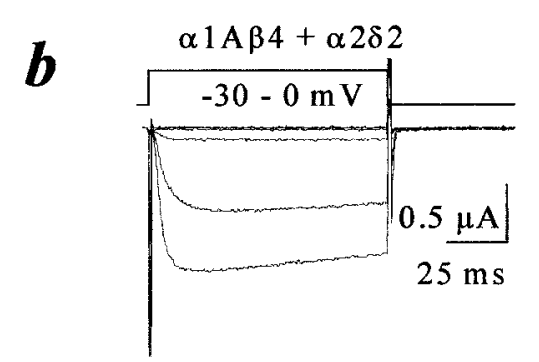

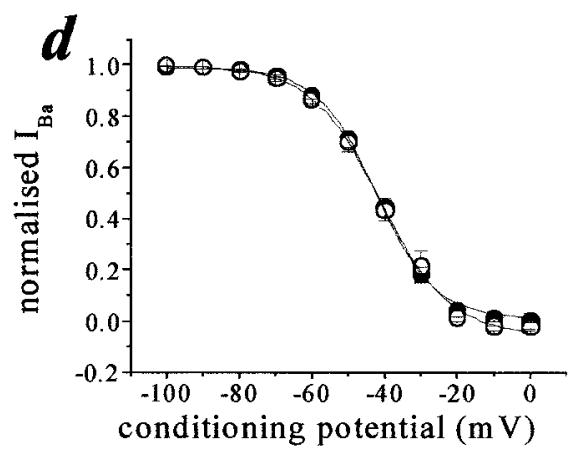

Figure 6. The effect of $\alpha 2 \delta 2$ on $\alpha 1 \mathrm{~A} / \beta 4$ calcium channel currents expressed in Xenopus oocytes. $a, b$, Calcium channel currents recorded in $5 \mathrm{mM} \mathrm{Ba}^{2+}$ from Xenopus oocytes injected with either $\alpha 1 \mathrm{~A} / \beta 4$ (a) or $\alpha 1 \mathrm{~A} / \alpha 2 \delta 2 / \beta 4(b)$. For clarity, only the currents on the rising phase of the $I-V$ relationship are shown. $c, I-V$ relationship of $\alpha 1 \mathrm{~A} / \beta 4(\bigcirc)$ and $\alpha 1 \mathrm{~A} / \alpha 2 \delta 2 / \beta 4$ (-) peak currents $(n=14$ and 13 , respectively). The mean $I-V$ relationships were fitted with a combined Boltzmann and linear fit, as described in Materials and Methods. No significant differences were observed in the $V_{\text {rev }}$ or $k$ (results not shown). $d$, Steadystate inactivation of $\alpha 1 \mathrm{~A} / \beta 4(\bigcirc)$ and $\alpha 1 \mathrm{~A} / \alpha 2 \delta 2 / \beta 4$ (๑) currents ( $n=14$ and 13, respectively) were obtained by stepping to the conditioning potential for 25 sec, before measuring the current at the test potential of $0 \mathrm{mV}$. Individual data were fitted with a single Boltzmann equation of the form $I / I_{\max }=1 /(1+$ $\left.\exp \left[\left(V-V_{50}\right) / k\right]\right)$, where $k$ is the slope factor and $V_{50}$ is the voltage for $50 \%$ steady-state inactivation of the current. The $V_{50 \text { (inactivation) }}$ was $-41.73 \pm 1.0 \mathrm{mV}$ for $\alpha 1 \mathrm{~A} / \beta 4$ and $-41.68 \pm 1.1 \mathrm{mV}$ for $\alpha 1 \mathrm{~A} / \alpha 2 \delta 2 / \beta 4$. the voltage for $50 \%$ activation shifting from $-6.4 \pm 0.7$ to $-12.0 \pm 1.4 \mathrm{mV}(p<0.01)$ (Fig. $6 c)$. The maximum conductance was increased from $0.013 \pm 0.003$ to $0.036 \pm 0.005 \mu \mathrm{S}$ by coexpression of $\alpha 2 \delta 2$. There was no effect of $\alpha 2 \delta 2$ on steady-state inactivation of $\alpha 1 \mathrm{~A} / \beta 4$ currents (Fig. $6 d$ ).

\section{$\mathrm{Ca}^{2+}$ channel currents in $d u / d u$ Purkinje cells and granule cells}

The effects of $\alpha 2 \delta 2$ on the $\alpha 1 \mathrm{~A} / \beta 4$ current in vitro suggested that loss of wild-type $\alpha 2 \delta 2$ may result in a reduction in $\mathrm{Ca}^{2+}$ current density. To test this, $I_{\mathrm{Ba}}$ was examined in acutely dissociated cerebellar PCs from $\mathrm{P} 4-\mathrm{P} 8$ mice. $I_{\mathrm{Ba}}$ density was clearly reduced in the PCs from $d u / d u$ compared with $+/+$ and $+/ d u$ mice (Fig. $7 a, b)$. There was no effect on voltage dependence of activation (Fig. $7 a$ ) or on the kinetics of activation or inactivation (data not shown). Cell size, as determined by the capacitance, was not significantly different between the genotypes, being $14.9 \pm 1.4$, $15.1 \pm 0.9$, and $17.6 \pm 1.7 \mathrm{pF}$ in the $+/+,+/ d u$, and $d u / d u \mathrm{PCs}$, respectively. To examine the basis for the reduction in the wholecell $I_{\mathrm{Ba}}$ in $d u / d u \mathrm{PCs}$, single P-type $\mathrm{Ca}^{2+}$ channels were examined in the cell-attached mode from $+/+,+/ d u$, and $d u / d u$ PCs (Fig. $7 c$ ). There was no difference in the single-channel conductance or amplitude between the three genotypes (Fig. $7 d$ ). In cultured cerebellar GCs, taken from P6-P8 mice, there was no significant difference in $I_{\mathrm{Ba}}$ density at any potential (Fig. 7e,f) or in cell capacitance between the genotypes.

\section{DISCUSSION}

Our data provide strong evidence that the ducky phenotype is associated with mutations in the Cacna $2 d 2$ gene. This is discussed together with a consideration of the normal expression pattern and function of the VDCC $\alpha 2 \delta 2$ accessory subunit it encodes and how disruption of this function leads to the phenotypic features of ataxia and spike-wave seizures.

\section{Cacna2d2 is disrupted in $d u$ and $d u^{2 \mathrm{~J}}$ mice}

These studies demonstrate that wild-type Cacna2d2 transcript is absent from the brain of $d u / d u$ and $d u^{2 J} / d u^{2 J}$ mice. In $d u / d u$ mice, a genomic rearrangement disrupts Cacna $2 d 2$ and duplicates a nonfunctional open reading frame, region $\mathrm{X}$, although the exact mechanism remains unclear. Mutant transcripts 1 and 2 are present at very low levels in $d u / d u$ mice and, if translated, would encode proteins that are unlikely to function normally. The product of mutant transcript 1 would lack most of the $\alpha 2$ subunit and the $\delta$ subunit that includes the transmembrane domain, whereas that of mutant transcript 2 is unlikely to be trafficked correctly without a signal sequence. In $d u^{2 J} / d u^{2 J}$ mice, a 2 bp deletion in exon 9 of Cacna $2 d 2$ would result in a truncated protein lacking $>800$ amino acids, including the transmembrane domain. This is the first mammalian phenotype associated with disruption of an $\alpha 2 \delta$ subunit gene and should allow the physiological roles of $\alpha 2 \delta 2$ and the other $\alpha 2 \delta$ subunits to be characterized further.

\section{Cacna2d2 is predominantly expressed in mouse brain}

Northern analysis of $C A C N A 2 D 2$ in human tissue showed highest expression in heart, pancreas, and skeletal muscle and lower levels in kidney, liver, placenta, and brain (Klugbauer et al., 1999). A separate study reported highest expression in lung and testis and significant levels in brain, heart, and pancreas (Gao et al., 2000) and suggested that the pattern in the former study may reflect cross-hybridization of the probe with $C A C N A 2 D 1$. The expression pattern presented here corresponds more closely with the latter study, and the differences observed (particularly in lung) may be attributed to species differences and/or developmental differences. This is not unprecedented (Fougerousse et al., 2000).

In brain, Cacna $2 d 2$ expression was highest in cerebellar PCs but was also detected in cerebral cortex, hippocampus, cerebellar GCs, nRT, habenula, pons, and medulla. The genes encoding the $\alpha 2 \delta 1, \alpha 2 \delta 2$, and $\alpha 2 \delta 3$ subunits show generally distinct patterns of expression within the cerebellum. Cacna $2 d 1$ is predominantly expressed in the GCL, Cacna2d2 is predominant in the Purkinje cell layer (PCL), and Cacna2d3 expression is detected in the molecular layer (ML) (Klugbauer et al., 1999; Hobom et al., 2000; present study). Most of the $\alpha 1, \beta$, and $\gamma$ subunit genes share at least one region of expression with Cacna2d2, making it difficult to predict in vivo interactions based on expression profiles. However, the similarity of the ducky phenotype to that observed in mice with mutations in genes encoding the $\alpha 1 \mathrm{~A}$ and $\beta 4$ subunits (Fletcher et al., 1996; Burgess et al., 1997) and their predominant 
Figure 7. Calcium channel currents in cerebellar Purkinje cells and granule cells. $a, I-V$ relationships in PCs from $+/+(n=19),+/ d u(n=32)$, and $d u / d u$ $(n=14)$ mice. Genotypes as indicated in the figure. Cells were held at $-80 \mathrm{mV}$. At $-10 \mathrm{mV}$, the $I_{\mathrm{Ba}}$ density was $-84.9 \pm 8.2,-90.5 \pm 7.8$, and $-54.2 \pm$ $8.9 \mathrm{pA} / \mathrm{pF}$ in the $+/+,+/ d u$, and $d u / d u$ PCs, respectively $(p<0.05$ for $d u / d u$ vs $+/+; p<0.01$ for $d u / d u$ vs $+/ d u)$. There was no significant difference between the genotypes in the kinetics of activation or in the inactivation over $50 \mathrm{msec}$. The $10-90 \%$ rise times at $-10 \mathrm{mV}$ were $3.5 \pm 0.2,3.4 \pm 0.2$, and $3.9 \pm 0.2 \mathrm{msec}$ in $+/+,+/ d u$, and $d u / d u$ PCs, respectively, and the respective percentage of inactivation in $50 \mathrm{msec}$ was $13.6 \pm 1.3,16.4 \pm 0.9$, and $17.1 \pm 2.0 \%$. Calibration: $30 \mathrm{pA} / \mathrm{pF}, 20$ msec. $b$, Example current traces from $+/+,+/ d u$, and $d u / d u$ PCs. The currents were elicited by $50 \mathrm{msec}$ voltage steps from -70 to $-10 \mathrm{mV}$. $I_{\mathrm{Ba}}$ density is reduced in PCs from $d u / d u$ mice compared with $+/+$ mice. $c, \mathrm{Ca}^{2+}$ channel activity in cellattached patches from PCs of $+/+$ (left ; two overlapping openings are evident, indicative of at least two channels active in the patch of membrane recorded), $+/ d u$ (middle; two channels in patch), and $d u / d u$ (right; single channel) mice. Top, The voltage protocol; holding potential, $-70 \mathrm{mV}$; test potential, +20 $\mathrm{mV}$, for $500 \mathrm{msec}$, delivered every $5 \mathrm{sec}$. Three representative current traces are shown for each cell; openings are downward deflections, and the horizontal lines that run through the traces represent the closed state. Calibration: 1 pA, 250 msec. $d$, Similar singlechannel conductance for VDCCs in PCs of $+/+$, $+/ d u$, and $d u / d u$ mice using the same symbols as in $a$. Single-channel amplitudes were measured at three different voltages and averaged for each population. $n=3-4,4-5$, and $2-6$ patches for $+/+$, $+/ d u$, and $d u / d u$, respectively. The single-channel conductance was determined by fitting a linear function to the mean data and was $13.8,11.4$, and $13 \mathrm{pS}$, respectively. $e, I-V$ relationships for $\mathrm{GCs}$ from $+/+(n=35),+/ d u(n=18)$, and $d u / d u(n=$

23) mice. Cells were held at $-70 \mathrm{mV}$. The mean $I-V$ relationships were fitted with a combined Boltzmann and linear fit. $f$, Example current traces from $+/+,+/ d u$, and $d u / d u$ GCs. The currents shown were elicited by $100 \mathrm{msec}$ depolarizing voltage steps from -50 to $+15 \mathrm{mV}$. Calibration: 10 $\mathrm{pA} / \mathrm{pF}, 50 \mathrm{msec}$.

PC expression pattern suggests that $\alpha 2 \delta 2$ contributes to the P-type current.

\section{$\alpha \mathbf{2 \delta 2}$ interacts in vitro with the $\alpha \mathbf{1 A} / \beta \mathbf{4}$ combination}

In vitro studies have shown that $\alpha 2 \delta 1$ and $\alpha 2 \delta 3$ subunits increase peak current amplitude and alter the kinetics of inactivation for a number of different $\alpha 1$ subunits (Walker and De Waard, 1998; Dolphin et al., 1999; Klugbauer et al., 1999). In vitro studies with human $\alpha 2 \delta 2$ also demonstrate increased peak current amplitude for several $\alpha 1$ subunits (Gao et al., 2000). Our results show that mouse $\alpha 2 \delta 2$ causes a 2.8-fold increase in maximum conductance for the $\alpha 1 \mathrm{~A} / \beta 4$ subunit combination when coexpressed in Xenopus oocytes.

\section{Mechanism of the altered $\mathrm{Ca}^{2+}$ channel current in du/du PCs}

The in vitro expression data suggested that disruption of $\alpha 2 \delta 2$ expression in ducky mice may result in a decrease of the $\mathrm{Ca}^{2+}$ channel current in cells that express Cacna2d2. Electrophysiological recordings from isolated $d u / d u$ PCs confirmed this hypothesis, with a $35 \%$ decrease in the peak P-type $\mathrm{Ca}^{2+}$ current density in $d u / d u$ compared with $+/+$ PCs. This result has been confirmed recently by $\mathrm{Ca}^{2+}$ imaging experiments (J. Brodbeck and A. C. Dolphin, unpublished results). Furthermore, the comparable single P-type $\mathrm{Ca}^{2+}$ channel conductance in the two genotypes indicates that the reduction in $I_{\mathrm{Ba}}$ density reflects either a change in the number of functional channels or their open probability. The ducky mouse represents the first example of an accessory VDCC subunit mutant with a measurable effect in PCs. Recordings from $\alpha 1 \mathrm{~A}$ mutant mice PCs also revealed changes in the P-type $\mathrm{Ca}^{2+}$ current compared with that in wild-type PCs (Dove et al., 1998; Lorenzon et al., 1998; Wakamori et al., 1998; Jun et al., 1999). Similar studies performed on lethargic mice, however, showed no differences from wild type, potentially as a result of compensation by other $\beta$ subunits (Burgess et al., 1999). The low levels of Cacna2d1 and Cacna2d3 transcripts in the PCs may preclude such compensation in PCs of $d u / d u$ mice, and indeed no upregulation of these mRNAs was seen in $d u / d u$ PCs. In vitro recordings from cultured $d u / d u$ and $+/+$ GCs demonstrated no significant difference in the $\mathrm{Ca}^{2+}$ channel current, consistent with the lower expression levels of Cacna2d2 in the GCL.

\section{Calcium channel dysfunction and the ducky phenotype}

It is likely that several features of the ducky phenotype, including the SWDs, ataxia, and paroxysmal dyskinesia, are attributable to loss of full-length functional $\alpha 2 \delta 2$ in neurons of ducky mice. The occurrence of these traits in other mice with mutations in genes encoding VDCC subunits supports this hypothesis.

Homozygous Cacnala ${ }^{\text {tg }}, \mathrm{Cacnb}^{\text {lh }} \mathrm{Cacng}^{\text {stg }}, d u$, and $d u^{2 J}$ mice 
all exhibit generalized bilaterally symmetrical SWDs with a frequency of 5-7Hz (Noebels and Sidman, 1979; Noebels et al., 1990; Hosford et al., 1992; present study). Evidence from animal models suggests that SWDs are generated by aberrant thalamocortical oscillations involving neocortical pyramidal neurons, thalamic relay neurons, and GABAergic neurons of the nRT (Snead, 1995). T-type $\mathrm{Ca}^{2+}$ currents underlie thalamic oscillations, and VDCCs have an essential role in presynaptic release of neurotransmitters, providing two potential mechanisms linking $\mathrm{Ca}^{2+}$ currents and thalamocortical circuits (Coulter, 1997). Reduction of excitatory but not inhibitory synaptic transmission in the thalamus of lethargic and tottering mice has been documented previously (Caddick et al., 1999), and it was proposed that a net enhanced GABAergic input in thalamocortical neurons may synchronize them into a burst firing mode. In contrast, hippocampal neurotransmitter release appears to be stabilized by a $\mathrm{Ca}^{2+}$ current compensatory mechanism in the same mice (Qian and Noebels, 2000). Additional work is required to elucidate the mechanism of SWD generation in ducky mice. However, the expression of Cacna2d2 within the nRT and cortical pyramidal neurons suggests a similar mechanism may be involved.

An ataxic gait is first detectable between P10 and P21 in tottering, lethargic, stargazer, and ducky homozygotes (Snell, 1955; Green and Sidman, 1962; Dickie, 1964; Noebels et al., 1990). The high levels of expression of all the corresponding VDCC subunit genes in cerebellar neurons, particularly PCs, provides an obvious anatomical correlate with the presumed cerebellar dysfunction underlying the ataxia. PC loss has been documented in some, but not all, of these mutant strains; for example, it is observed in $\operatorname{tg}^{l a}$ (Heckroth and Abbott, 1994). In $d u / d u$ mice, no loss of PC somata was seen, but preliminary findings indicate major PC dendritic abnormalities (Brodbeck and Dolphin, unpublished results). The $d u / d u$ PCs in which a reduced $\mathrm{Ca}^{2+}$ channel current was documented were obtained, for technical reasons, from ducky mice too young and developmentally immature to manifest an ataxic gait. However, it is reasonable to assume that the functional deficit is also present in older mice, and its presence before the overt phenotype is seen demonstrates that it is not merely a secondary effect. It is noteworthy that mutations in the human ortholog of the tottering gene $C A C N A 1 A$ are associated with ataxia and are also associated in vitro with a reduced whole-cell $\mathrm{Ca}^{2+}$ channel current (Hans et al., 1999).

There is one noticeable phenotypic difference between the $d u / d u$ and $d u^{2 J} / d u^{2 J}$ mice. Homozygous $d u^{2 J}$ mice lack the characteristic "ducky" gait, potentially reflecting differences in the relative effects or stabilities of the mutant gene products. Additionally, the two mutations are maintained on different genetic backgrounds ( $d u$ on TKDU and $d u^{2 J}$ on C57BLKS/J), and this has an effect in other channelopathy phenotypes (Sprunger et al., 1999). Alternatively, these differences could result from involvement of other genes that are either disrupted or duplicated by the $d u$ rearrangement but unaltered in $d u^{2 J} / d u^{2 J}$ mice. Several other genes lie within the $d u$ interval, including a semaphorin (Sekido et al., 1996).

These observations complete the association of mutations in all four main categories of VDCC subunits with a phenotype in mouse that includes SWDs and ataxia. A central role for disturbed neuronal calcium channel function can therefore be invoked. In the case of $\alpha 2 \delta 2$, this is reinforced by the finding that a high-affinity binding site of the anti-epileptic drug gabapentin in brain has been identified as $\alpha 2 \delta$ (Gee et al., 1996). In conclusion, these observations extend the occurrence of epileptogenic muta- tions to the last major category of genes encoding VDCC subunits and further strengthen the argument that such genes represent an important class of candidates for human IGEs.

\section{REFERENCES}

Barclay J, Rees M (2000) Genomic organisation of the mouse and human $\alpha 2 \delta 2$ voltage dependent calcium channel subunit genes. Mamm Genome 11:1142-1144.

Berridge MJ, Bootman MD, Lipp P (1998) Calcium: a life and death signal. Nature 395:645-648.

Blatt C, Eversole-Cire P, Cohn VH, Zollman S, Fournier RE, Mohandas LT, Nesbitt M, Lugo T, Jones DT, Reed RR, Weiner LP, Sparkes RS Simon MI (1988) Chromosomal localization of genes encoding guanine nucleotide-binding protein subunits in mouse and human. Proc Natl Acad Sci USA 85:7642-7646.

Burgess DL, Jones JM, Meisler MH, Noebels JL (1997) Mutation of the $\mathrm{Ca}^{2+}$ channel $\beta$ subunit gene $C \operatorname{chb} 4$ is associated with ataxia and seizures in the lethargic $(l h)$ mouse. Cell 88:385-392.

Burgess DL, Biddlecombe GH, McDonough SI, Diaz ME, Zilinski CA, Bean BP, Campbell KP, Noebels JL (1999) Beta subunit reshuffling modifies $\mathrm{N}$ - and $\mathrm{P} / \mathrm{Q}$-type $\mathrm{Ca}^{2+}$ channel subunit compositions in lethargic mouse brain. Mol Cell Neurosci 13:293-311.

Burgess DL, Gefrides LA, Foreman PJ, Noebels JL (2001) A cluster of three novel $\mathrm{Ca}^{2+}$ channel $\gamma$ subunit genes on chromosome 19q13.4: evolution and expression profile of the $\gamma$ subunit gene family. Genomics 71:339-350.

Caddick SJ, Wang C, Fletcher CF, Jenkins NA, Copeland NG, Hosford DA (1999) Excitatory but not inhibitory synaptic transmission if reduced in lethargic (Cacnb4 $\left.4^{l h}\right)$ and tottering $\left(\right.$ Cacnala $\left.{ }^{t g}\right)$ mouse thalami. J Neurophysiol 81:2066-2074.

Canti C, Page KM, Stephens GJ, Dolphin AC (1999) Identification of residues in the $\mathrm{N}$ terminus of $\alpha 1 \mathrm{~B}$ critical for inhibition of the voltagedependent calcium channel by G $\beta \gamma$. J Neurosci 19:6855-6864.

Catterall WA (1998) Structure and function of neuronal $\mathrm{Ca}^{2+}$ channels and their role in neurotransmitter release. Cell Calcium 24:307-323.

Coulter DA (1997) Thalamocortical anatomy and physiology. In: Epilepsy: a comprehensive textbook (Pedley JE, Pedley TA, eds), pp 341-351. Philadelphia: Lippincott-Raven.

Cox GA, Lutz CM, Yang C-L, Biemesderfer D, Bronson RT, Fu A Aronson PS, Noebels JL, Frankel WN (1997) Sodium/hydrogen exchanger gene defect in slow-wave epilepsy mutant mice. Cell 91:139-148.

Dickie MM (1964) Lethargic (lh) mouse. Mouse News Lett 30:31.

Dietrich WF, Miller J, Steen R, Merchant MA, Damron-Boles D, Husain Z, Dredge R, Daly MJ, Ingalls KA, O'Connor TJ, Evans CA, DeAngelis MM, Levinson DM, Kruglyak L, Goodman N, Copeland NG, Jenkins NA, Hawkins TL, Stein L, Page DC, Lander ES (1996) A comprehensive genetic map of the mouse genome. Nature 380:149-152.

Dolphin AC, Wyatt CN, Richards J, Beattie RE, Craig P, Lee J-H, Cribbs LL, Volsen SG, Perez-Reyes E (1999) The effect of $\alpha 2-\delta$ and other accessory subunits on expression and properties of the calcium channel $\alpha 1 \mathrm{G}$. J Physiol (Lond) 519:35-45.

Dove LS, Abbott LC, Griffith WH (1998) Whole-cell and single-channel analysis of P-type calcium currents in cerebellar Purkinje cells of leaner mutant mice. J Neurosci 18:7687-7699.

Eisenstat DD, Liu JK, Mione M, Zhong W, Yu G, Anderson SA, Ghattas I, Puelles L, Rubenstein JL (1999) DLX-1, DLX-2, and DLX-5 expression define distinct stages of basal forebrain differentiation. J Comp Neurol 414:217-237.

Ertel EA, Campbell KP, Harpold MM, Hofmann F, Mori Y, Perez-Reyes E, Schwartz A, Snutch TP, Tanabe T, Birnbaumer L, Tsien RW, Catterall WA (2000) Nomenclature of voltage-gated calcium channels. Neuron 25:533-535.

Fletcher CF, Lutz CM, O'Sullivan TNJ, Hawkes R, Frankel WN, Copeland NG, Jenkins NA (1996) Absence epilepsy in tottering mutant mice is associated with calcium channel defects. Cell 87:606-617.

Fougerousse F, Bullen P, Herasse M, Lindsay S, Richard I, Wilson D, Suel L, Durand M, Robson S, Abitbol M, Beckmann JS, Strachan T (2000) Human-mouse differences in the embryonic expression patterns of developmental control genes and disease genes. Hum Mol Genet 9:165-173.

Gao B, Sekido Y, Maximov A, Saad M, Forgacs E, Latif F, Wei MH, Lerman M, Lee J-H, Perez-Reyes E, Besprozvanny I, Minna JD (2000) Functional properties of a new voltage-dependent calcium channel $\alpha 2 \delta$-2 auxiliary subunit gene (CACNA2D2). J Biol Chem 275:12237-12242

Gee NS, Brown JP, Dissanayake VU, Offord J, Thurlow R, Woodruff GN (1996) The novel anticonvulsant drug, gabapentin (neurontin), binds to the $\alpha 2 \delta$ subunit of a calcium channel. J Biol Chem 271:5768-5776.

Green MC, Sidman RL (1962) Tottering: a neuromuscular mutation in the mouse. J Hered 53:233-237.

Haldi M, Stickland C, Linm P, VanBerkel V, Chen X, Noya D, Korenberg J, Husain Z, Miller J, Lander E (1996) A comprehensive large-insert 
yeast artificial chromosome library for physical mapping of the mouse genome. Mamm Genome 10:767-769.

Hans M, Luvisetto S, Williams ME, Spagnolo M, Urrtia A, Tottene A, Brust PF, Johnson EC, Harpold MM, Stauderman KA, Pietrobon D (1999) Functional consequences of mutations in the human $\alpha 1 \mathrm{~A}$ calcium channel subunit linked to familial hemiplegic migraine. J Neurosci 19:1610-1619.

Heckroth JA, Abbott LC (1994) Purkinje cell loss from alternating sagittal zones in the cerebellum of leaner mutant mice Brain Res 658:93-104.

Hobom M, Dai S, Marais E, Lacinova L, Hofmann F, Klugbauer N (2000) Neuronal distribution and functional characterization of the calcium channel $\alpha 2 \delta 2$ subunit. Eur J Neurosci 12:1217-1226.

Hosford DA, Clark S, Cao Z, Wilson WA, Lin F-H, Morrisett RA, Huin A (1992) The role of $\mathrm{GABA}_{\mathrm{B}}$ receptor activation in absence seizures of lethargic $(l h / l h)$ mice. Science 257:398-401.

Hosford DA, Lin F-H, Kraemer DL, Cao Z, Wang Y, Wilson JT (1995) Neural network of structures in which $\mathrm{GABA}_{\mathrm{B}}$ receptors regulate absence seizures in the lethargic $(l h / l h)$ mouse model. J Neurosci 15:7367-7376.

Jun K, Piedras-Renteria ES, Smith SM, Wheeler DB, Lee SB, Lee TG, Chin H, Adams ME, Scheller RH, Tsien RW, Shin HS (1999) Ablation of $\mathrm{P} / \mathrm{Q}$-type $\mathrm{Ca}^{2+}$ channel currents, altered synaptic transmission, and progressive ataxia in mice lacking the alpha1A-subunit. Proc Natl Acad Sci USA 96:15245-15250.

Klugbauer N, Lacinova L, Marais E, Hobom M, Hofmann F (1999) Molecular diversity of the calcium channel $\alpha 2 \delta$ subunit. J Neurosci 19:684-691.

Letts VA, Felix R, Biddlecombe GH, Arikkath J, Mahaffey CL, A V, Bartlett FS, Mori Y, Campbell KP, Frankel WN (1998) The mouse stargazer gene encodes a neuronal $\mathrm{Ca}^{2+}$-channel $\gamma$ subunit. Nat Genet 19:340-347.

Lorenzon NM, Lutz CM, Frankel WN, Beam KG (1998) Altered calcium channel currents in Purkinje cells of the neurological mutant mouse leaner. J Neurosci 18:4482-4489.

Meier H (1968) The neuropathology of ducky, a neurological mutation of the mouse. A pathological and preliminary histochemical study. Acta Neuropathol (Berl) 11:15-28.

Meir A, Bell DC, Stephens GJ, Page KM, Dolphin AC (2000) Calcium channel $\beta$ subunit promotes voltage-dependent modulation of $\alpha 1 \mathrm{~B}$ by Gb $\gamma$. Biophys J 79:731-746.

Mintz IM, Adams ME, Bean BP (1992) P-type calcium channels in rat central and peripheral neurons. Neuron 9:85-95.

Neher E (1995) Voltage offsets in patch-clamp experiments. In: Singlechannel recording (Sakmann B, Neher E, eds), pp 147-153. New York: Plenum.

Noebels JL (1991) Mutational analysis of spike-wave epilepsy phenotypes. In: Genetic strategies in epilepsy research (Anderson VE,
Hauser WA, Leppik IE, Noebels JL, Rich SS, eds), pp 201-212. Amsterdam: Elsevier.

Noebels JL, Sidman RL (1979) Inherited epilepsy: spike-wave and focal motor seizures in the mutant mouse tottering. Science 204:1334-1336.

Noebels JL, Qiao X, Bronson RT, Spencer C, Davisson MT (1990) Stargazer: a new neurological mutant on chromosome 15 in the mouse with prolonged cortical seizures. Epilepsy Res 7:129-135.

Noebels JL, Fariello RG, Jobe PC, Lasley SM, Marescaux C (1997) Genetic models of generalized epilepsy. In: Epilepsy: a comprehensive textbook. (Pedley JE, Pedley TA, eds), pp 457-465. Philadelphia: Lippincott-Raven.

Nusbaum C, Slonim DK, Harris KL, Birren BW, Steen R, Stein LD, Miller J, Dietrich WF, Nahf R, Wang V, et al. (1999) A YAC-based physical map of the mouse genome. Nat Genet 22:388-393.

Pearson HA, Sutton KG, Scott RH, Dolphin AC (1995) Characterization of $\mathrm{Ca}^{2+}$ channel currents in cultured rat cerebellar granule neurones. J Physiol (Lond) 482:493-509.

Puranam HA, McNamara JO (1999) Seizure disorders in mutant mice: relevance to human epilepsies. Curr Opin Neurobiol 9:281-287.

Qian J, Noebels JL (2000) Presynaptic Ca ${ }^{2+}$ influx at a mouse central synapse with $\mathrm{Ca}^{2+}$ channel subunit mutations. J Neurosci 20:163-170.

Sekido Y, S B, Latif F, Chen JY, Duh FM, Wei MH, Albanesi JP, Lee CC, Lerman M I, Minna JD (1996) Human semaphorins A(V) and IV reside in the 3 p21.3 small cell lung cancer deletion region and demonstrate distinct expression patterns. Proc Natl Acad Sci USA 93:4120-4125

Skynner M, Gangadharan U, Coulton GR, Mason RM, Nikitopolou A, Brown SD, Blanco G (1995) Genetic mapping of the mouse neuromuscular mutation kyphoscoliosis. Genomics 25:207-213.

Snead OC (1995) Basic mechanisms of generalized absence seizures Ann Neurol 37:146-157.

Snell GD (1955) Ducky, a new second chromosome mutation in the mouse. J Hered 46:27-29.

Sprunger LK, Escayg A, Tallaksen-Greene S, Albin RL, Meisler MH (1999) Dystonia associated with mutation of the neuronal sodium channel Scn8a and identification of the modifier locus Scnm1 on mouse chromosome 3. Hum Mol Genet 8:471-479.

Uchida K, Yoshimura A, Inazawa J, Yanagisawa K, Osada H, Masuda A, Saito T, Takahashi T, Miyajima A (1997) Molecular cloning of CISH, chromosome assignment to 3 p21.3, and analysis of expression in fetal and adult tissues. Cytogenet Cell Genet 78:209-212.

Wakamori M, Yamazaki K, Martsunodaira H, Teramoto T, Tanaka I, Niidomes T, Sawada K, Nishizawa Y, Sekiguchi N, Mori E, Mori Y, Imoto K (1998) Single tottering mutations responsible for the neuropathic phenotype of the P-type calcium channel. J Biol Chem 273:34857-34867.

Walker D, De Waard M (1998) Subunit interaction sites in voltagedependent $\mathrm{Ca}^{2+}$ channels: role in channel function. Trends Neurosci 21:148-154. 